\title{
A THEORETICAL AND EXPERIMENTAL STUDY ON HYDROGEN-BONDING INTERACTIONS BETWEEN GUANAZOLE AND DMSO/WATER
}

\author{
Mustafa Tuğfan Bilkan \\ Department of Physics, Faculty of Science, Çankırı Karatekin University, 18100 Çankır, Turkey \\ mtbilkan@gmail.com
}

In this paper, guanazole-DMSO/water complexes, formed by hydrogen bonding interactions, were investigated by a combined experimental and computational approach. Two conformations of guanazole molecule were considered. Seven hydrogen-bonded guanazole-DMSO/water $\left(\mathrm{C}_{2} \mathrm{H}_{6} \mathrm{OS} / \mathrm{H}_{2} \mathrm{O}\right)$ complexes were characterized in terms of geometries, energies and vibrational frequencies. The optimizations and calculations were performed for the complexes by Density Functional Theory. In the experimental part, the $\mathrm{C}_{2} \mathrm{H}_{6} \mathrm{OS} / \mathrm{H}_{2} \mathrm{O}$ (DMSO/water) solutions of guanazole were prepared and infrared spectra of the solutions were recorded. After the solvation process, significant shifts in the existing bands and appearance of new bands were observed in the experimental spectra of guanazole. The following results are found from this study: 1) guanazole (I) is more stable than guanazole (II). 2) Seven guanazole- $\mathrm{C}_{2} \mathrm{H}_{6} \mathrm{OS}$ and guanazole- $\mathrm{H}_{2} \mathrm{O}$ complexes are investigated. All nitrogen atoms of guanazole are hydrogen bond acceptors and all hydrogen atoms are hydrogen bond donors. 3) Aqueous complexes of guanazole form stronger hydrogen bonds compared to $\mathrm{C}_{2} \mathrm{H}_{6} \mathrm{OS}$ complexes. 4) The complexes with the most stable structures have lpO $\cdots \mathrm{H}-\mathrm{N}$ and $\mathrm{lpN} \cdots \mathrm{H}-\mathrm{O}$ type intermolecular interactions. For these interactions, hydrogen-bond lengths of 1.78 and $1.90 \AA$ are calculated and interaction energies are $-7.10 \mathrm{~kJ} / \mathrm{mol}$ for guanazole- $\mathrm{C}_{2} \mathrm{H}_{6} \mathrm{OS}$ and $-50.5 \mathrm{~kJ} / \mathrm{mol}$ for guanazole- $\mathrm{H}_{2} \mathrm{O}$. Based on this energy difference between the complexes, guanazole forms more stable complexes with water molecules compared to $\mathrm{C}_{2} \mathrm{H}_{6} \mathrm{OS}$ molecules, and with this property, it is an ideal molecule for pharmacological purposes.

Keywords: guanazole; solvent effects; hydrogen bonding; DFT; FT-IR spectroscopy

\section{ТЕОРИСКО И ЕКСПЕРИМЕНТАЛНО ИСТРАЖУВАҢЕ НА ИНТЕРАКЦИИТЕ НА ВОДОРОДНО СВРЗУВАњЕ МЕЃУ ГВАНАЗОЛ И DМSО/ВОДА}

Во овој труд беа истражени водородните интеракции меѓу комплексите на гваназолDMSO/вода со комбиниран експериментален и теориски пристап. Предвид беа земени два конформера на гванозолската молекула. Карактеризирани беа седум водородно сврзани комплекси на гваназол-DMSO/вода $\left(\mathrm{C}_{2} \mathrm{H}_{6} \mathrm{OS} / \mathrm{H}_{2} \mathrm{O}\right)$ во смисла на нивната геометрија, енергија и вибрациски фреквенции. Оптимизациите и пресметките на комплексите беа извршени со теоријата на густина на функционалот. Во експерименталниот дел беа приготвени раствори на $\mathrm{C}_{2} \mathrm{H}_{6} \mathrm{OS} / \mathrm{H}_{2} \mathrm{O}$ (DMSO/вода) на гваназол и беа снимени нивните инфрацрвени спектри. По процесот на растворање беше забележано значајно поместување на постојните ленти и појава на нови ленти во експерименталните спектри на гваназол. Од ова истражување се добиени следниве резултати: 1) гваназол (I) е постабилен од гваназол (II). 2) Испитани беа седум комплекси на гваназол- ${ }_{2} \mathrm{H}_{6} \mathrm{OS}$ и гваназол- $\mathrm{H}_{2} \mathrm{O}$. Сите азотни атоми на гваназол се акцептори на врски и сите водородни атоми се донори на водородни врски. 3) Водни комплекси на гваназол образуваат посилни водородни врски во споредба со комплексите на $\mathrm{C}_{2} \mathrm{H}_{6} \mathrm{OS}$. 4) Комплексите со најстабилни структури имаат тип на интеракции $\mathrm{lpO} \cdots \mathrm{H}-\mathrm{N}$ и $\mathrm{lpN} \cdots \mathrm{H}-\mathrm{O}$. За овие интеракции на водородните врски е пресметано дека должините им се 1,78 и $1,90 \AA$ и енергијата на интерациите $-7,10 \mathrm{~kJ} / \mathrm{mol}$ за гваназол- $\mathrm{C}_{2} \mathrm{H}_{6} \mathrm{OS}$ и $-50,5 \mathrm{~kJ} / \mathrm{mol}$ за гваназол- $\mathrm{H}_{2} \mathrm{O}$. Врз основа на овие разлики во енергиите меѓу комплексите, 
гваназол образува постабилни комплекси со молекулите на вода одошто со молекулите на $\mathrm{C}_{2} \mathrm{H}_{6} \mathrm{OS}$ и поради ова својство е идеална молекула за фармаколошки цели.

Клучни зборови: гваназол; ефекти на растворувачи; водородно сврзување; DFT; FT-IR спектроскопија

\section{INTRODUCTION}

3,5-Diamino-1,2,4-triazole (guanazole) is a considerable biomolecule and with antitumor, anticancer and antimicrobial effects on living tissues [1-3]. Researches on the biological, medical and pharmacological properties of guanazole is still popular [4-7], and since the determination of the biological, chemical, and physical properties of such effective compounds is of great importance, many studies have been published on these properties of guanazole in the literature. Kumar et al. recorded the infrared (IR) spectrum of guanazole and calculated basic vibrational modes by using Density Functional Theory (DFT) [8]. Similarly, in another study, Guennoun et al. [9] calculated geometric parameters, energies and vibrational modes of guanazole using Hartree-Fock (HF) and DFT levels. In addition, there are many studies published on metal complexes of guanazole in the literature [10-13].

To the best of our knowledge, although there are many published studies on vibrational frequencies of guanazole, the studies on hydrogen-bonding interactions between guanazole and solvent molecules are very limited. Karpińska and Dobrowolski completed a theoretical study on the energetics of tautomers and conformers of guanazole in the gas phase and in water [14]. For this reason, a theoretical and experimental study of hydrogen-bonded guanazole- $\mathrm{C}_{2} \mathrm{H}_{6} \mathrm{OS} / \mathrm{H}_{2} \mathrm{O}$ complexes was carried out in this paper, in order to overcome this deficiency in the literature.

Determining of the effects of solvent media on the structural properties of any molecule is an important issue in computational quantum chemistry. Solvent media is one factor involved in the absorption, transport, and diffusion of drugs taken into living tissues and cells. Although many models and methods have been described for the investigation of solvent effects on molecular structures, few of them are close to explaining experimental results. Such calculations are very costly and difficult to make with high reliability. One of the reasonable models for analyzing the effects of solvent environments on molecular structures is the Polarizable Continuum Model (PCM) [15]. This model significantly reduces calculation costs. However, it is not enough to use this model alone to study sol- vent-ligand interactions. Instead, using both implicit and explicit models is necessary to make calculations more acceptable.

In this work, $\mathrm{C}_{2} \mathrm{H}_{6} \mathrm{OS}$ and $\mathrm{H}_{2} \mathrm{O}$ have been selected as solvents for the investigation of intermolecular interactions between solvent molecules and guanazole. Although $\mathrm{C}_{2} \mathrm{H}_{6} \mathrm{OS}$ may have some side effects on living cells, it is sometimes known to be used in a number of medical applications [16]. Similarly, $\mathrm{H}_{2} \mathrm{O}$ is known as the most important solvent for chemical and biological processes, and it is essential for living organisms. Therefore, these liquids are very important for the investigation of intermolecular interactions. For the calculations, DFT chosen because, among electronic structure methods, it has given very successful results for intermolecular interactions. In many studies in the literature using this theory, efficient results have been obtained. Calculations with DFT are also known to be very successful in explaining experimental results. The investigations were done with both explicit and implicit approaches. In the experimental study section, Fourier Transform Infrared Spectroscopy was selected to reveal the hydrogenbonding interactions from an experimental viewpoint. The obtained results from calculations were matched with experimental data, and the effects of the solvent environment on guanazole are discussed in detail.

\section{COMPUTATIONAL METHODS}

Three-dimensional geometries of the structures were drawn with the help of the Gaussview visualization program [17]. By using drawn structures, all calculations on energies, molecular parameters and vibrational frequencies for guanazole were performed with the Gaussian09 program [18]. The calculations in vacuum, DMSO, and aqueous media were performed by the DFT/6-311++G(d,p) method on a high capacity computer. All vibrational modes were calculated from the optimized structures. The potential energy distribution (PED), obtained by using the VEDA4 program, was used to characterize fundamental vibrational modes [19]. The calculated vibrational frequencies were scaled by 0.9668 to correct the differences between the calculated and experimental results [20]. 
Molecular interaction energies between solvent molecules and guanazole can be obtained as the energetic difference between the sum of the monomers and the complexes. In this case, interaction energies for guanazole- $\mathrm{C}_{2} \mathrm{H}_{6} \mathrm{OS}$ and guanazole- $\mathrm{H}_{2} \mathrm{O}$ complexes are $\Delta E_{\text {interaction }}=E_{\text {complex }}-\left(E_{\text {guanazole }}+E_{\mathrm{C}_{2} \mathrm{H}_{6} \mathrm{OS}}\right)$ and $\Delta E_{\text {interaction }}=E_{\text {complex }}-\left(E_{\text {guanazole }}+E_{\mathrm{H}_{2} \mathrm{O}}\right)$, respectively. The counterpoise method [21], defined by Boys and Bernardi, was used to correct the basis set superposition error and better estimate the binding energies of the complexes. The PCM implicit solvation model calculations were named Model I and both implicit and explicit solvation model calculations were named Model II.

\section{EXPERIMENTAL PROCEDURES}

A commercial sample of guanazole $(98 \%$ purity) was purchased from Sigma-Aldrich and used without further purification. Two mmol of guanazole (about $200 \mathrm{mg}$ ) were dissolved in either $5 \mathrm{ml}$ of $\mathrm{C}_{2} \mathrm{H}_{6} \mathrm{OS}$ and $5 \mathrm{ml}$ of purified $\mathrm{H}_{2} \mathrm{O}$, and the solutions were stirred at $40{ }^{\circ} \mathrm{C}$ for 10 minutes, yielding fully saturated solutions. The solutions were filtered before making spectroscopic measurements. The IR spectra of the solutions, free ligand, and pure solvents were recorded between $3750-550 \mathrm{~cm}^{-1}$ by Perkin Elmer Spectrum 100 FTIR spectrometer with ATR (Attenuated Total Reflection) equipment. The spectra were recorded at room temperature with a resolution of $2 \mathrm{~cm}^{-1}$. The IR spectra of pure solvents were used as reference while recording spectra of the solutions. Before the spectra of the solutions were recorded, the solvents were filtered to remove precipitates.

\section{RESULTS AND DISCUSSION}

\subsection{Monomer geometry analysis and atomic charges}

The two conformational structures of guanazole molecule considered in this work are given in Figure 1, as guanazole (I) and guanazole (II).

The distances between the $12 \mathrm{H}$ atom and the hydrogen atoms attached to the $6 \mathrm{~N}$ and $7 \mathrm{~N}$ atoms are greater in guanazole (I) than guanazole (II).
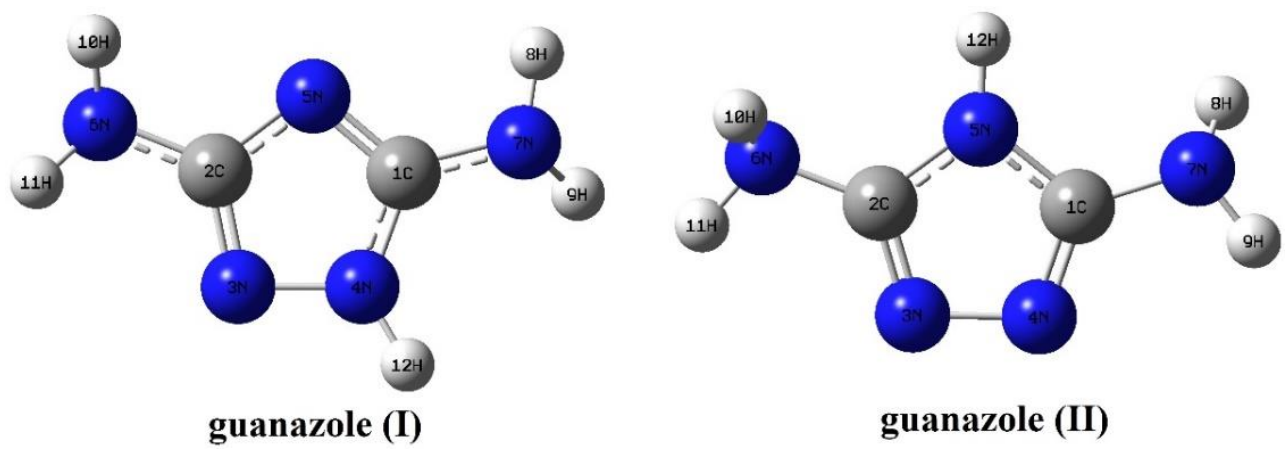

Fig. 1. Optimized conformational structures of guanazole (I) and guanazole (II) with labels for carbon, nitrogen and hydrogen atoms

Thus, the repulsion forces between hydrogen atoms are less, which allows guanazole (I) to be more stable (lower energy) than guanazole (II). The calculated energy difference between two structures is $9.95 \mathrm{Kcal} / \mathrm{Mol}$, and this energy difference is quite large. According to the relative population analysis, it can be said that probability of guanazole (I) being found of is $100 \%$. The Boltzmann distribution (Eq. I) is used to obtain relative populations [22].

$$
\begin{aligned}
& \frac{N_{i}}{N}=\frac{\rho_{i} e^{E_{i} / k_{b} T}}{Z(T)} \\
& Z(T)=\sum_{i} \rho_{i} e^{E_{i} / k_{b} T}
\end{aligned}
$$

Here, $Z(T)$ is the partition function, $k b$ is Boltzmann's constant, $T$ (Kelvin) is absolute temperature, $E_{i}$ is the $i$. energy level, and $\rho_{i}$ is the number of states with energy $E_{i}$. According to the calculations, guanazole (I) is the most stable structure in both vacuum and solvent media and further calculations will be carried out only for this structure.

The optimized bond lengths, bond angles, and dihedral angles for guanazole, calculated in vacuum and solvent media using the DFT/6$311++\mathrm{G}(\mathrm{d}, \mathrm{p})$ method, are listed in Table 1 together with the experimental $\mathrm{X}$-ray crystal data from the literature [23]. 
T a b le 1

Optimized geometrical parameters of guanazole monomer in vacuum, $\mathrm{C}_{2} \mathrm{H}_{6} \mathrm{OS}$ and $\mathrm{H}_{2} \mathrm{O}$ at DFT/6-311++G(d,p) level with experimental $X$-ray crystal data from literature

\begin{tabular}{|c|c|c|c|c|c|c|c|c|c|}
\hline Bond lengths $(\AA)$ & Vacuum & $\mathrm{C}_{2} \mathrm{H}_{6} \mathrm{OS}$ & $\mathrm{H}_{2} \mathrm{O}$ & X-ray.* & Bond lengths $(\AA)$ & Vacuum & $\mathrm{C}_{2} \mathrm{H}_{6} \mathrm{OS}$ & $\mathrm{H}_{2} \mathrm{O}$ & X-ray.* \\
\hline $1 \mathrm{C}-4 \mathrm{~N}$ & 1.349 & 1.343 & 1.343 & 1.339 & $3 \mathrm{~N}-4 \mathrm{~N}$ & 1.386 & 1.389 & 1.389 & 1.398 \\
\hline $1 \mathrm{C}-5 \mathrm{~N}$ & 1.320 & 1.334 & 1.335 & 1.363 & $4 \mathrm{~N}-12 \mathrm{H}$ & 1.006 & 1.023 & 1.024 & 0.870 \\
\hline $1 \mathrm{C}-7 \mathrm{~N}$ & 1.380 & 1.367 & 1.367 & 1.353 & $6 \mathrm{~N}-10 \mathrm{H}$ & 1.009 & 1.017 & 1.018 & 0.830 \\
\hline $2 \mathrm{C}-3 \mathrm{~N}$ & 1.319 & 1.324 & 1.324 & 1.319 & $6 \mathrm{~N}-11 \mathrm{H}$ & 1.009 & 1.018 & 1.018 & 0.930 \\
\hline $2 \mathrm{C}-5 \mathrm{~N}$ & 1.371 & 1.368 & 1.368 & 1.363 & $7 \mathrm{~N}-8 \mathrm{H}$ & 1.011 & 1.018 & 1.018 & 0.890 \\
\hline $2 \mathrm{C}-6 \mathrm{~N}$ & 1.380 & 1.381 & 1.381 & 1.376 & $7 \mathrm{~N}-9 \mathrm{H}$ & 1.010 & 1.018 & 1.018 & 0.860 \\
\hline \multicolumn{10}{|l|}{ Bond angles $\left({ }^{\circ}\right)$} \\
\hline $4 \mathrm{~N}-1 \mathrm{C}-5 \mathrm{~N}$ & 110.4 & 110.0 & 110.0 & 110.4 & $3 \mathrm{~N}-4 \mathrm{~N}-12 \mathrm{H}$ & 119.7 & 120.8 & 120.9 & 118.0 \\
\hline $4 \mathrm{~N}-1 \mathrm{C}-7 \mathrm{~N}$ & 124.1 & 124.4 & 124.4 & 124.1 & $1 \mathrm{C}-5 \mathrm{~N}-2 \mathrm{C}$ & 102.8 & 103.1 & 103.1 & 102.7 \\
\hline $5 \mathrm{~N}-1 \mathrm{C}-7 \mathrm{~N}$ & 125.5 & 125.5 & 125.4 & 125.4 & $2 \mathrm{C}-6 \mathrm{~N}-10 \mathrm{H}$ & 113.9 & 113.8 & 113.7 & 115.0 \\
\hline $3 N-2 C-5 N$ & 115.7 & 115.2 & 115.2 & 115.9 & $2 \mathrm{C}-6 \mathrm{~N}-11 \mathrm{H}$ & 114.5 & 114.3 & 114.2 & 114.0 \\
\hline $3 N-2 C-6 N$ & 123.1 & 123.2 & 123.2 & 122.9 & $10 \mathrm{H}-6 \mathrm{~N}-11 \mathrm{H}$ & 113.9 & 112.4 & 112.3 & 114.0 \\
\hline $5 \mathrm{~N}-2 \mathrm{C}-6 \mathrm{~N}$ & 121.1 & 121.5 & 121.5 & 121.0 & $1 \mathrm{C}-7 \mathrm{~N}-8 \mathrm{H}$ & 112.2 & 114.5 & 114.5 & 115.0 \\
\hline $2 \mathrm{C}-3 \mathrm{~N}-4 \mathrm{~N}$ & 101.4 & 101.7 & 101.7 & 101.5 & $1 \mathrm{C}-7 \mathrm{~N}-9 \mathrm{H}$ & 115.9 & 116.4 & 116.3 & 119.0 \\
\hline $1 \mathrm{C}-4 \mathrm{~N}-3 \mathrm{~N}$ & 109.8 & 109.9 & 109.9 & 109.5 & $8 \mathrm{H}-7 \mathrm{~N}-9 \mathrm{H}$ & 112.5 & 113.5 & 113.5 & 115.0 \\
\hline $1 \mathrm{C}-4 \mathrm{~N}-12 \mathrm{H}$ & 129.6 & 129.2 & 129.2 & 132.5 & & & & & \\
\hline \multicolumn{10}{|l|}{ Torsional angles $\left({ }^{\circ}\right)$} \\
\hline $5 N-2 C-3 N-4 N$ & -0.7 & -0.5 & -0.4 & - & $4 \mathrm{~N}-1 \mathrm{C}-7 \mathrm{~N}-9 \mathrm{H}$ & 38.4 & 24.9 & 24.8 & - \\
\hline $5 \mathrm{~N}-1 \mathrm{C}-4 \mathrm{~N}-12 \mathrm{H}$ & -170.1 & -0.7 & -178.8 & - & $5 \mathrm{~N}-1 \mathrm{C}-7 \mathrm{~N}-8 \mathrm{H}$ & -13.6 & -23.2 & -23.6 & - \\
\hline $7 \mathrm{~N}-1 \mathrm{C}-4 \mathrm{~N}-12 \mathrm{H}$ & 7.3 & -1.7 & -2.1 & - & $5 \mathrm{~N}-1 \mathrm{C}-7 \mathrm{~N}-9 \mathrm{H}$ & -144.7 & -158.9 & -159.1 & - \\
\hline $7 \mathrm{~N}-1 \mathrm{C}-4 \mathrm{~N}-3 \mathrm{~N}$ & 175.8 & 176.0 & 176.0 & - & $3 \mathrm{~N}-2 \mathrm{C}-6 \mathrm{~N}-11 \mathrm{H}$ & 22.1 & 22.5 & 22.6 & - \\
\hline $4 \mathrm{~N}-1 \mathrm{C}-7 \mathrm{~N}-8 \mathrm{H}$ & 169.4 & 160.6 & 160.2 & - & $2 \mathrm{C}-3 \mathrm{~N}-4 \mathrm{~N}-12 \mathrm{H}$ & 171.1 & 178.6 & 179.0 & - \\
\hline
\end{tabular}

*Data were taken from Ref. [23].

The $2 \mathrm{C}-6 \mathrm{~N}, 1 \mathrm{C}-4 \mathrm{~N}$ and $1 \mathrm{C}-7 \mathrm{~N}$ bonds exhibit single bond character, while $1 \mathrm{C}-5 \mathrm{~N}$ and $2 \mathrm{C}-3 \mathrm{~N}$ bonds show typical double bond character. In vacuum, single $\mathrm{C}-\mathrm{N}$ bond lengths were calculated between $1.350-1.380 \AA$ whereas double $\mathrm{C}-\mathrm{N}$ bonds were calculated to be $1.320 \AA$. In $\mathrm{C}_{2} \mathrm{H}_{6} \mathrm{OS}$ and $\mathrm{H}_{2} \mathrm{O}$ media, $2 \mathrm{C}-6 \mathrm{~N}, 1 \mathrm{C}-4 \mathrm{~N}$ and $1 \mathrm{C}-7 \mathrm{~N}$ bonds were calculated to be $1.381,1.343$, and $1.367 \AA$ respectively. As seen from the table, the measured experimental values of these bonds are 1.376, 1.339 , and $1.353 \AA$. The lengths of the double $\mathrm{C}=\mathrm{C}$ bonds were calculated to be shorter the single $\mathrm{C}-\mathrm{C}$ bonds, and the average energies of $\mathrm{C}-\mathrm{C}$ and $\mathrm{C}=\mathrm{C}$ bonds are known to be about 350 and $600 \mathrm{~kJ} / \mathrm{mol}$, respectively. The bond lengths between the $1 \mathrm{C}-5 \mathrm{~N}$ and $1 \mathrm{C}-7 \mathrm{~N}$ atoms are the bond parameters most affected by the change of environment. When passed from vacuum to water, the bond length of $1 \mathrm{C}-5 \mathrm{~N}$ increased while the bond length of $1 \mathrm{C}-7 \mathrm{~N}$ decreased. The main reason for this change is that, when the PCM is included in the calculations for
$\mathrm{H}_{2} \mathrm{O}$, the $12 \mathrm{H}-9 \mathrm{H}$ interaction is relatively reduced because of a continuous dielectric environment. Thus, while the $1 \mathrm{C}-7 \mathrm{~N}$ bond length is reduced in the solvent medium, the $1 \mathrm{C}-5 \mathrm{~N}$ bond length increases. Though the $12 \mathrm{H}-9 \mathrm{H}$ distance was $2.756 \AA$ in vacuum, this length decreased to $2.638 \AA$ in $\mathrm{H}_{2} \mathrm{O}$ medium.

When DFT calculated bond angles are examined, it can be seen that almost all of the angles changed in the $\mathrm{H}_{2} \mathrm{O}$ environment. The alterations caused by the environment change are more serious at the angles between the atoms outside the ring and are small, as expected, at the angles between the atoms remaining in the plane of the triazole ring. Another important review here is related to dihedral angles. Dihedral angles can give very important information about how molecules are effected by changing physical conditions. In particular, planar structures can exhibit very precise changes for dihedral angles due to external physical effects. 
In Table 1, some important dihedral angles of guanazole are presented for vacuum, $\mathrm{C}_{2} \mathrm{H}_{6} \mathrm{OS}$ and $\mathrm{H}_{2} \mathrm{O}$ environments. The solvent-induced changes had considerable effects on the dihedral angles. The $5 \mathrm{~N}-2 \mathrm{C}-3 \mathrm{~N}-4 \mathrm{~N}$ dihedral angle is very close to $180^{\circ}$ and $0^{\circ}$. This result shows that the triazole portion is almost planar and this increases in the solvent environments. The $4 \mathrm{~N}-1 \mathrm{C}-7 \mathrm{~N}-8 \mathrm{H}$ and $4 \mathrm{~N}-1 \mathrm{C}-7 \mathrm{~N}-9 \mathrm{H}$ dihedral angles between the triazole ring and diamine portion of the molecule were calculated to be approximately $169^{\circ}-160^{\circ}$, and $38^{\circ}-25^{\circ}$, respectively, which indicates that the molecular structure of guanazole is non-planar. As seen from the table, others dihedral angles vary by less than $1^{\circ}$, while some vary by more than $14^{\circ}$. If these changes are carefully examined, similar to the case of the bond angles, the dihedral angles in the triazole ring plane are effected less by the ambient change, while those outside the ring are much more effected. Nevertheless, all of the optimized geometric parameters, except for $\mathrm{N}-\mathrm{H}$ bond lengths, are quite consistent with the experimental results from the literature, further verifying the calculated results of this work. The reason for the differences in N-H bond lengths between calculated and measured values are experimental errors that cannot be solved and they were caused by scattering factors in X-ray experiments.

Table 2

The calculated NBO atomic charges of guanazole in vacuum, $\mathrm{C}_{2} \mathrm{H}_{6} \mathrm{OS}$ and $\mathrm{H}_{2} \mathrm{O}$ media (in e)

\begin{tabular}{cccccccc}
\hline \hline Atoms & Vacuum & $\mathrm{C}_{2} \mathrm{H}_{6} \mathrm{OS}$ & $\mathrm{H}_{2} \mathrm{O}$ & Atoms & Vacuum & $\mathrm{C}_{2} \mathrm{H}_{6} \mathrm{OS}$ & $\mathrm{H}_{2} \mathrm{O}$ \\
\hline $1 \mathrm{C}$ & 0.560 & 0.572 & 0.573 & $7 \mathrm{~N}$ & -0.803 & -0.819 & -0.819 \\
$2 \mathrm{C}$ & 0.518 & 0.522 & 0.522 & $8 \mathrm{H}$ & 0.395 & 0.420 & 0.420 \\
$3 \mathrm{~N}$ & -0.403 & -0.464 & -0.465 & $9 \mathrm{H}$ & 0.378 & 0.417 & 0.418 \\
$4 \mathrm{~N}$ & -0.409 & -0.417 & -0.417 & $10 \mathrm{H}$ & 0.384 & 0.407 & 0.407 \\
$5 \mathrm{~N}$ & -0.601 & -0.661 & -0.663 & $11 \mathrm{H}$ & 0.383 & 0.407 & 0.407 \\
$6 \mathrm{~N}$ & -0.803 & -0.836 & -0.837 & $12 \mathrm{H}$ & 0.402 & 0.453 & 0.454 \\
\hline \hline
\end{tabular}

The calculated atomic charges of guanazole are given in Table 2. The calculation of atomic charges is an important indication of possible molecular sites. Especially when solvent-ligand interactions are examined, the identification of the atomic charges belonging to the ligand can provide important information regarding the nature of the complex structures to be formed. All of the nitrogen atoms of guanazole have negative charges, while all of the carbon atoms have positive charges. The $6 \mathrm{~N}$ and $7 \mathrm{~N}$ atoms have the most negative charges in the molecule. These results show that all of the nitrogen and hydrogen atoms in guanazole have the potential to form hydrogen bonds with solvent molecules. When passed from vacuum to solvent environments, the negative charges of the nitrogen atoms increase, while the positive charges of hydrogen atoms increase more drastically. This indicates that the hydrogen-bonded complexes to be installed in the $\mathrm{C}_{2} \mathrm{H}_{6} \mathrm{OS}$ and aquatic environments may be even more stable.

Molecular electrostatic potential (MEP) maps are drawings that visualize the distribution of charges on the molecule in three dimensions. These maps give the shape, size and charge distribution of a molecule. Generally, in the MEP maps, red colors represent electron-rich regions, while blue colors represent electron-poor regions. MEP maps also provide important information about the nature of molecular bonds and they say a lot about the difference in electronegativity.

To predict reactive sites for electrophilic and nucleophilic attacks of guanazole, the MEP was calculated, and in Figure 2, the MEP map is drawn as transparent.

Figure 2 shows that, for both structures of the molecule, the atoms with the greatest number of electrons are nitrogen atoms as expected, while the positive charges are concentrated on $9 \mathrm{H}$ and $12 \mathrm{H}$ atoms. Thus, hydrogen-bonded $\mathrm{C}_{2} \mathrm{H}_{6} \mathrm{OS}$ complexes, in which $\mathrm{C}_{2} \mathrm{H}_{6} \mathrm{OS}$ molecules are attached to $8 \mathrm{H}, 9 \mathrm{H}$, and $12 \mathrm{H}$ atoms, are more stable than other cases. In aqueous complexes, hydrogen-bonded versions formed between hydrogen atoms of $\mathrm{H}_{2} \mathrm{O}$ molecules and electron-rich nitrogen atoms of guanazole molecules are the most stable ones. 


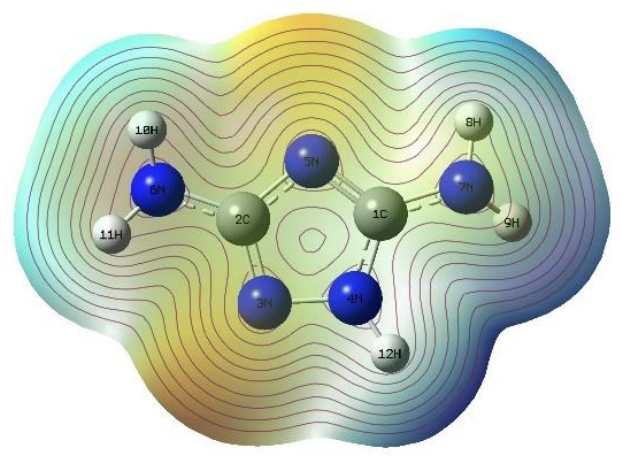

guanazole (I)

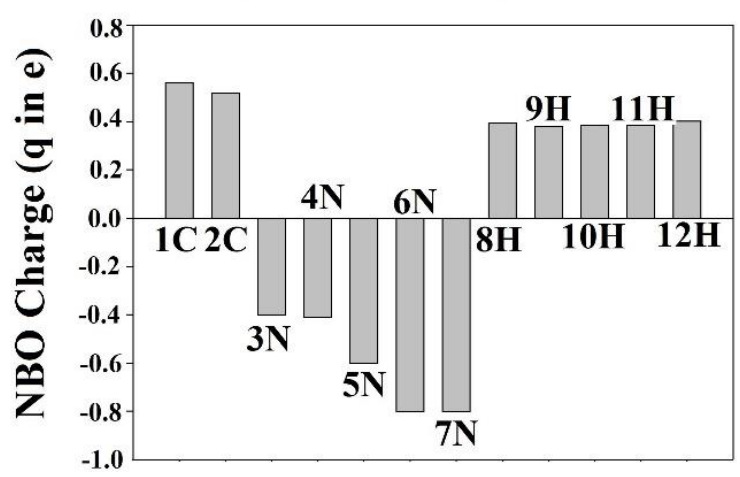

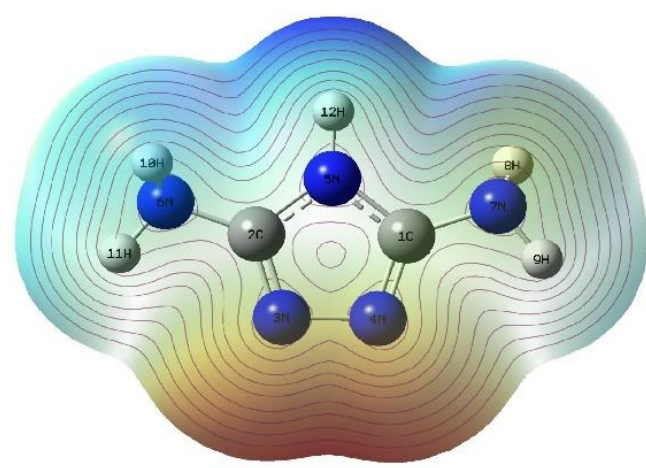

guanazole (II)

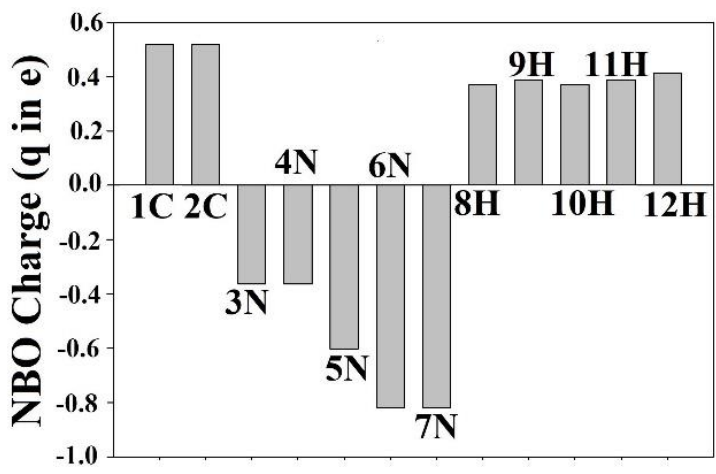

Fig. 2. MEP maps and histogram of the calculated NBO charges for guanazole (I) and guanazole (II)

\subsection{Interaction energies and optimized geometries of guanazole- $\mathrm{C}_{2} \mathrm{H}_{6} \mathrm{OS} / \mathrm{H}_{2} \mathrm{O}$ complexes}

Hydrogen bonds are important determining factors in the formation of physical and chemical properties of fluids and solutions. Ligand $-\mathrm{H}_{2} \mathrm{O}$ complexes occur mostly in the form of noncovalent bonds. Such bindings contain some important parameters that provide useful information about the nature of the interaction. The interaction energy is one such important parameter which provides a lot of information about solvent-ligand complexes. Highly accurate determination of the interaction energy is possible by obtaining optimized structures of complexes. In this study, hydrogen-bonded complexes formed by guanazole molecules with $\mathrm{C}_{2} \mathrm{H}_{6} \mathrm{OS}$ and $\mathrm{H}_{2} \mathrm{O}$ molecules are given in Figures 3 and 4, respectively.

As shown in the figures, the most stable optimized structures in both complexes are V1. Both guanazole- $\mathrm{C}_{2} \mathrm{H}_{6} \mathrm{OS}$ and guanazole- $\mathrm{H}_{2} \mathrm{O}$ complexes have seven interaction structures. The binding distances of the structures are in the range of 1.78$2.58 \AA$ and these values are less than the sum of the Van der Waals radii of hydrogen and oxygen (2.5-2.6 $\AA$ ) [24]. This distance is very critical for determining the existence of intermolecular hydrogen bonds. $\mathrm{C}_{2} \mathrm{H}_{6} \mathrm{OS}$ has an oxygen atom with lone pairs (Lp) of electrons. In the same way, the oxygen atom in $\mathrm{H}_{2} \mathrm{O}$ molecule has two Lp of electrons and these electrons provide weak bonds with the hydrogen atoms. The guanazole molecule has five hydrogen atoms and two open-ended nitrogen atoms. The nitrogen atoms of guanazole can bind with hydrogen atoms on $\mathrm{H}_{2} \mathrm{O}$ molecules. Intermolecular hydrogen bonds in the form of $1 \mathrm{pN} \cdots \mathrm{H}-\mathrm{O}$, $\mathrm{lpO} \cdots \mathrm{H}-\mathrm{N}$ and $\mathrm{lpN} \cdots \mathrm{H}-\mathrm{C}$ occur. The most stable complex structures have $1 \mathrm{pN} \cdots \mathrm{H}-\mathrm{O}$ and $\mathrm{lpO} \cdots \mathrm{H}-\mathrm{N}$ type intermolecular $\mathrm{H}$-bonds and the lengths of the bonds are 1.78 and $1.90 \AA$ in $\mathrm{C}_{2} \mathrm{H}_{6} \mathrm{OS}$ complexes and 1.90 and $1.89 \AA$ in $\mathrm{H}_{2} \mathrm{O}$ complexes, respectively. In addition, while all of the $\mathrm{H}_{2} \mathrm{O}$ complexes are singly connected, V3, V4, and V5 versions of guanazole- $\mathrm{C}_{2} \mathrm{H}_{6} \mathrm{OS}$ complexes are binary connected. The energy difference between the complex structures is quite small. The interaction energy is -7.10 $\mathrm{kJ} / \mathrm{mol}$ for $\mathrm{V} 1$ guanazole- $\mathrm{C}_{2} \mathrm{H}_{6} \mathrm{OS}$ complex and $-50.5 \mathrm{~kJ} / \mathrm{mol}$ for $\mathrm{V} 1$ version of guanazole $-\mathrm{H}_{2} \mathrm{O}$ complex. For a stable interaction complex, the interaction energy should be negative and the greater the energy value, the stronger the hydrogen bond strength. 

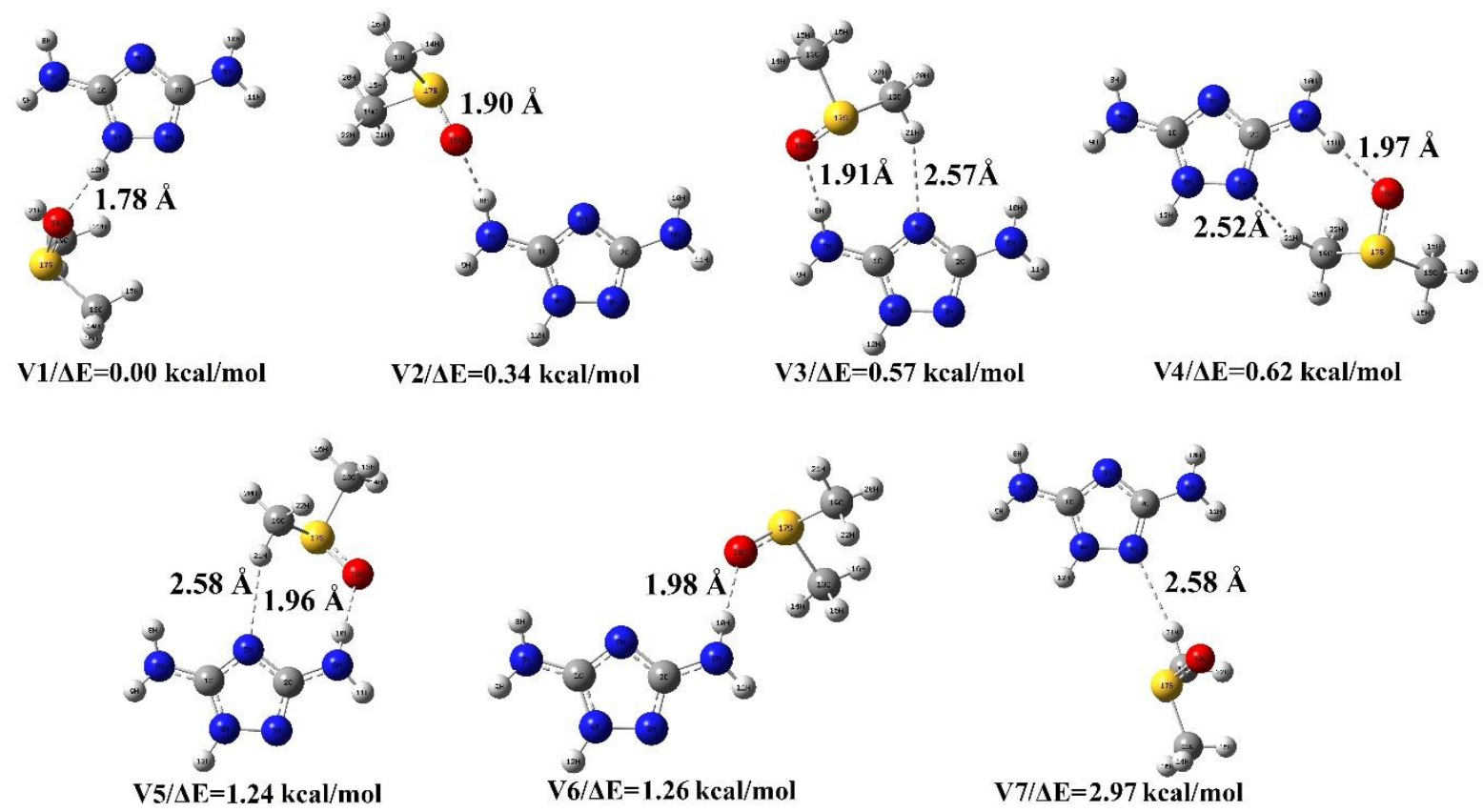

Fig. 3. Optimized geometric structures of guanazole- $\mathrm{C}_{2} \mathrm{H}_{6} \mathrm{OS}$ complexes

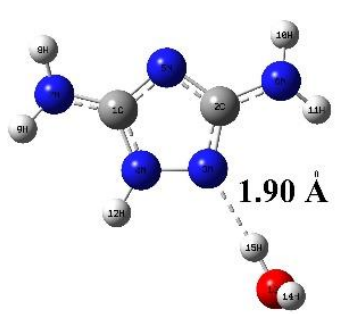

$\mathrm{V} 1 / \Delta \mathrm{E}=0.00 \mathrm{kcal} / \mathrm{mol}$
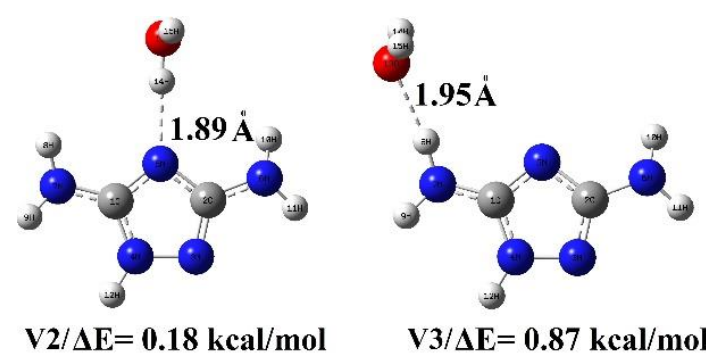

$\mathrm{V} 3 / \Delta \mathrm{E}=0.87 \mathrm{kcal} / \mathrm{mol}$

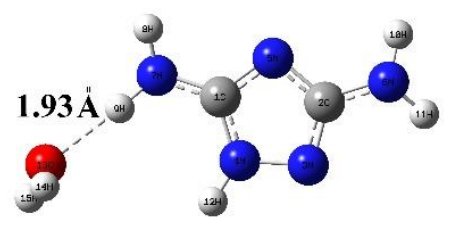

$\mathrm{V4} / \Delta \mathrm{E}=0.93 \mathrm{kcal} / \mathrm{mol}$

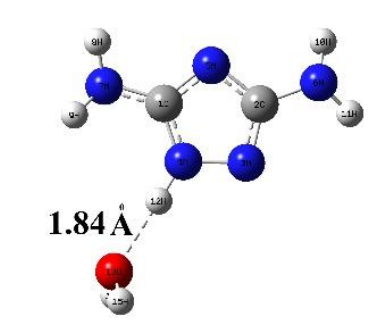

$\mathrm{V} 5 / \Delta \mathbf{E}=1.06 \mathrm{kcal} / \mathrm{mol}$

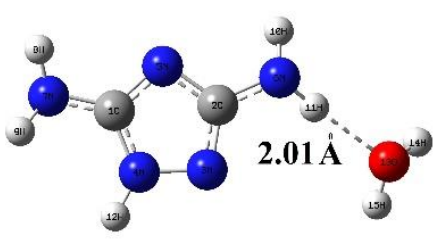

$\mathrm{V} 6 / \Delta \mathrm{E}=1.36 \mathrm{kcal} / \mathrm{mol}$

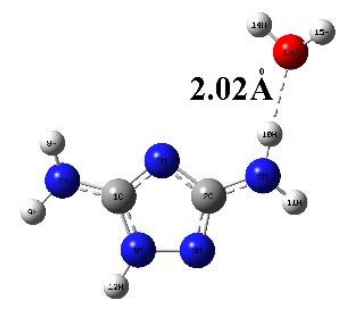

$\mathrm{V} 7 / \Delta \mathrm{E}=1.41 \mathrm{kcal} / \mathrm{mol}$

Fig. 4. Optimized geometric structures of guanazole- $\mathrm{H}_{2} \mathrm{O}$ complexes

In Figure 5, the interaction energies of the $\mathrm{C}_{2} \mathrm{H}_{6} \mathrm{OS} / \mathrm{H}_{2} \mathrm{O}$ complexes of guanazole are given as histograms. In particular, $\mathrm{H}_{2} \mathrm{O}$ complexes have much stronger hydrogen bonds than $\mathrm{C}_{2} \mathrm{H}_{6} \mathrm{OS}$ complexes. For guanazole- $\mathrm{C}_{2} \mathrm{H}_{6} \mathrm{OS}$, the energies of $\mathrm{V} 1, \mathrm{~V} 2, \mathrm{~V} 3$ and $\mathrm{V} 4$ are close to each other and significantly higher than V5, V6 and V7 structures. For guanazole- $\mathrm{H}_{2} \mathrm{O}$, the energies of the V1 and V2 are close to each other and significantly higher than other versions. This can also be attributed to the excellent solubility of guanazole in $\mathrm{H}_{2} \mathrm{O}$. 

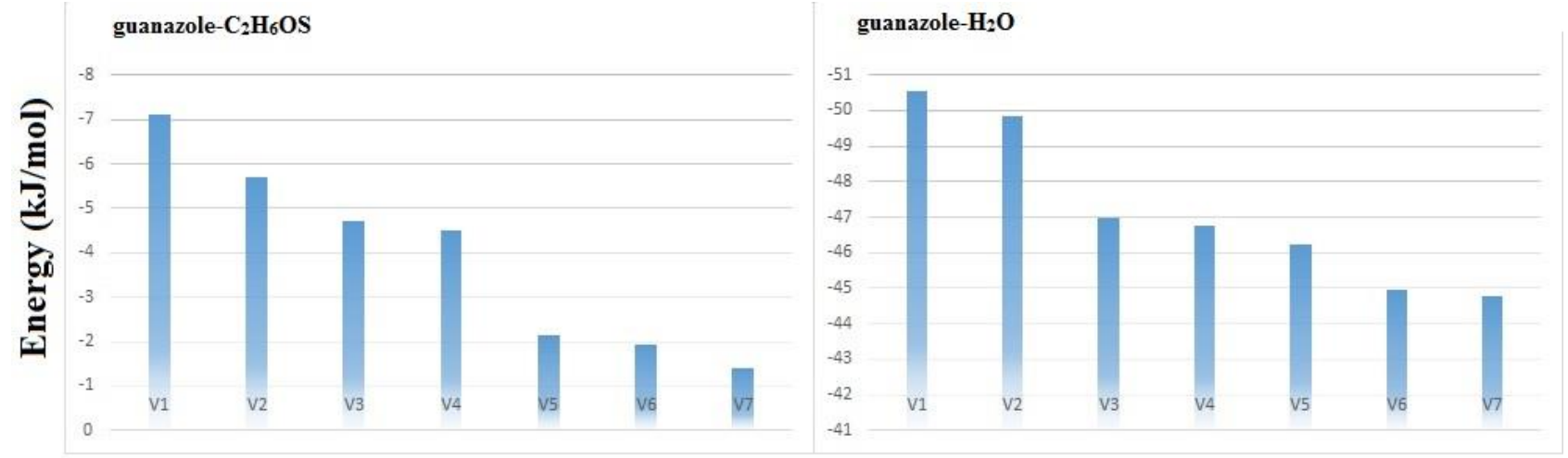

Fig. 5. Histogram for the interaction energies of guanazole- $\mathrm{C}_{2} \mathrm{H}_{6} \mathrm{OS} / \mathrm{H}_{2} \mathrm{O}$ complexes

\subsection{Vibrational modes of guanazole $-\mathrm{C}_{2} \mathrm{H}_{6} \mathrm{OS} / \mathrm{H}_{2} \mathrm{O}$ complexes}

It is known that external physical influences, such as temperature-pressure changes, hydrogen bonds, and solvent effects cause variation in molecular geometries and therefore shifts in vibrational modes. Such external influences also significantly affect intra-molecular and intermolecular hydrogen bonds. In particular, the solvent media effects both intramolecular bonds and intermolecular hydrogen bonds directly. Moreover, hydrogenbonding interactions can occur between the solvent and ligand molecules and this can cause new bands rising in the experimental IR spectrum. For determination of all these effects the existence of guanazole- $\mathrm{C}_{2} \mathrm{H}_{6} \mathrm{OS} / \mathrm{H}_{2} \mathrm{O}$ complexes were investigated experimentally and theoretically. In theoretical calculations, all of the interactions have been studied in solvent environments.

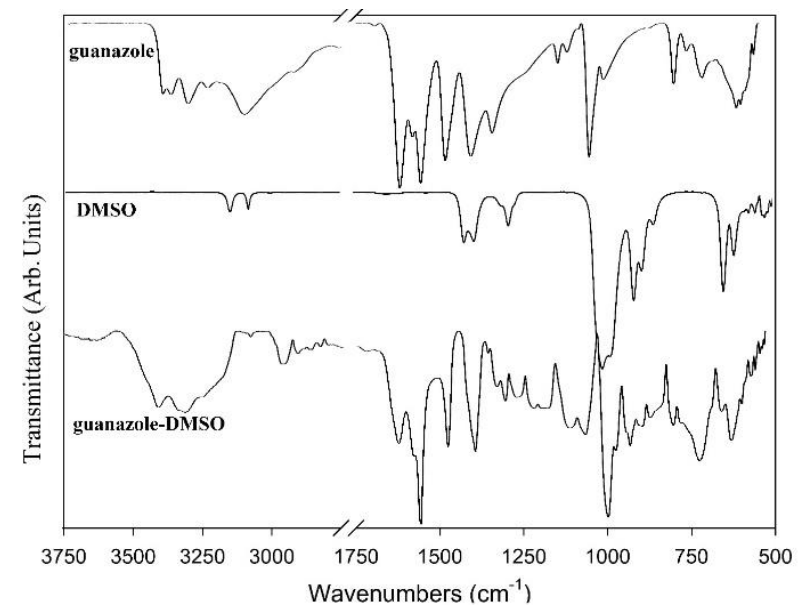

Fig. 6. Experimental IR spectra of guanazole, $\mathrm{C}_{2} \mathrm{H}_{6} \mathrm{OS}$ and guanazole- $\mathrm{C}_{2} \mathrm{H}_{6} \mathrm{OS}$ solution
The experimental IR spectra of the guanazole- $\mathrm{C}_{2} \mathrm{H}_{6} \mathrm{OS} / \mathrm{H}_{2} \mathrm{O}$ solutions were plotted in Figures 6 and 7 together with free ligand and solvent spectra. While the spectra of the solutions are recorded, the solvent spectra were used as backgrounds. The reason for this is that the vibrations of solvent-ligand interactions can be observed by eliminating the internal vibrations of the solvent molecules as much as possible. When the recorded spectra of solutions were compared with those of free ligand, it was seen that the spectral bands shifted and/or new bands arose. This shows that hydrogen-bonded complexes may form between solvent molecules and ligand molecules.

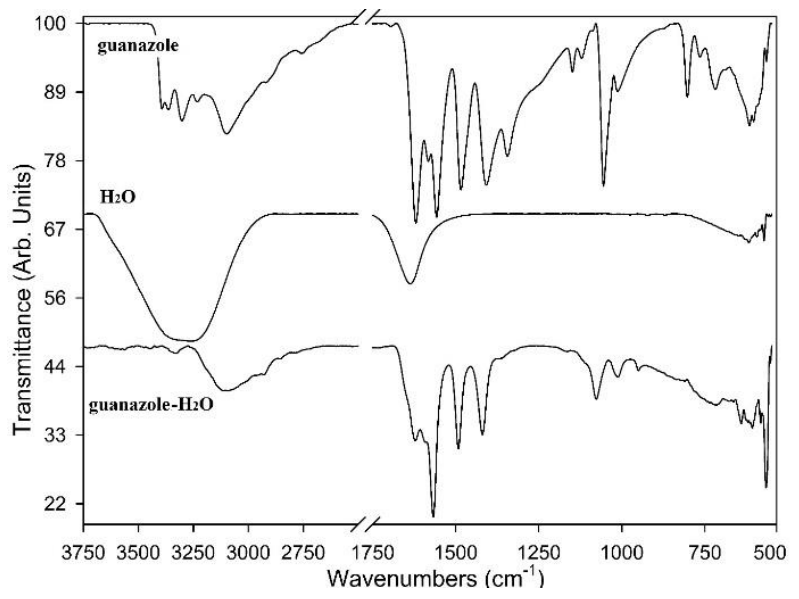

Fig. 7. Experimental IR spectra of guanazole, $\mathrm{H}_{2} \mathrm{O}$ and guanazole- $\mathrm{H}_{2} \mathrm{O}$ solution

For the most stable complex structures, vibrational frequencies and their relative intensities calculated by Model II (guanazole- $\mathrm{C}_{2} \mathrm{H}_{6} \mathrm{OS} / \mathrm{H}_{2} \mathrm{O}$ complex in solvent medium) and Model I (only guanazole in solvent medium) were given in Tables 3 and 4 alongside experimental values. 
T a ble 3

Vibrational modes of the most stable guanazole- $\mathrm{C}_{2} \mathrm{H}_{6} \mathrm{OS}$ complex (for V1)

\begin{tabular}{|c|c|c|c|c|c|c|}
\hline \multirow{2}{*}{ Mode } & \multicolumn{2}{|c|}{ Model II } & \multicolumn{2}{|c|}{ Model I } & \multirow{2}{*}{ Exp. } & \multirow{2}{*}{$\operatorname{PED}(\%)^{*}$} \\
\hline & Freq. & IIR & Freq. & IIR & & \\
\hline 18 & 548 & 24.20 & 515 & 94.29 & $565 \mathrm{w}$ & $\Gamma_{\mathrm{HNCN}}(75)+\delta_{\mathrm{HNH}}(11)$ \\
\hline 19 & 603 & 23.30 & 590 & 60.55 & $605 \mathrm{w}$ & $\Gamma_{\mathrm{HNCN}}(60)$ \\
\hline 20 & 621 & 0.27 & - & - & $618 w$ & $V_{\text {SC }}(94)$ \\
\hline 21 & 640 & 0.78 & 644 & 0.89 & $638 \mathrm{sh}$ & $\mathrm{V}_{\mathrm{NC}}(32)+\delta_{\mathrm{CNC}}(24)$ \\
\hline 22 & 655 & 0.75 & - & - & $648 \mathrm{~m}$ & Vsc(92) \\
\hline 23 & 673 & 2.12 & 689 & 2.79 & $678 w$ & $\Gamma_{\mathrm{NNNC}}(36)+\Gamma_{\mathrm{CNCN}}(14)$ \\
\hline 24 & 740 & 8.40 & 746 & 9.27 & $743 \mathrm{~s}$ & $\Gamma_{\mathrm{NCNC}}(36)+\Gamma_{\mathrm{NNNC}}(31)$ \\
\hline 25 & 775 & 1.57 & 778 & 2.80 & $772 \mathrm{~m}$ & $\delta_{\mathrm{NCN}}(60)+\mathrm{V}_{\mathrm{NC}}(23)$ \\
\hline 26 & 793 & 4.37 & - & - & $820 \mathrm{~m}$ & $\Gamma_{\mathrm{HNNC}}(28)+\Gamma_{\mathrm{CNCN}}(17)+\Gamma_{\mathrm{OHNC}}(15)$ \\
\hline 27 & 885 & 0.24 & - & - & $888 \mathrm{~m}$ & $\Gamma_{\mathrm{HCsc}}(66)$ \\
\hline 28 & 908 & 11.63 & - & - & $911 \mathrm{~m}$ & Vso(74) \\
\hline 29 & 921 & 0.75 & - & - & $946 \mathrm{~m}$ & $\Gamma \mathrm{HCSC}(50)$ \\
\hline 30 & 975 & 8.98 & - & - & $990 \mathrm{~m}$ & $\Gamma_{\text {HCsc }}(37)+V_{s o}(22)$ \\
\hline 31 & 997 & 0.07 & 988 & 3.25 & - & $\delta_{\mathrm{NCN}}(48)+\mathrm{V}_{\mathrm{NC}}(22)+\delta_{\mathrm{CNC}}(13)$ \\
\hline 32 & 1004 & 1.64 & - & - & 1011 vs & $\Gamma_{\mathrm{HCSC}}(62)$ \\
\hline 33 & 1029 & 2.29 & - & - & - & $\delta_{\mathrm{HNC}}(52)+\delta_{\mathrm{CNC}}(28)$ \\
\hline 34 & 1045 & 1.51 & 1030 & 1.76 & $1064 \mathrm{sh}$ & $\mathrm{V}_{\mathrm{NC}}(42)+\delta \mathrm{HNC}(12)$ \\
\hline 35 & 1084 & 1.09 & 1085 & 2.20 & $1078 \mathrm{~m}$ & $\mathrm{~V}_{\mathrm{NC}}(45)+\delta_{\mathrm{HNC}}(28)$ \\
\hline 36 & 1123 & 0.15 & 1024 & 10.74 & $1123 \mathrm{~m}$ & $\delta_{\mathrm{HNC}}(25)+\mathrm{V}_{\mathrm{NC}}(21)+\delta_{\mathrm{NCN}}(12)$ \\
\hline 37 & 1287 & 0.06 & - & - & $1280 \mathrm{w}$ & $\delta_{\mathrm{HCH}}(98)$ \\
\hline 38 & 1308 & 0.44 & - & - & 1314 w & $\delta_{\mathrm{HCH}}(97)$ \\
\hline 39 & 1338 & 2.09 & 1122 & 0.64 & $1338 \mathrm{w}$ & $\mathrm{V}_{\mathrm{NC}}(32)+\delta_{\mathrm{HNN}}(17)+\delta_{\mathrm{HNC}}(11)$ \\
\hline 40 & 1389 & 2.74 & - & - & - & $\delta \mathrm{HCH}(58)$ \\
\hline 41 & 1391 & 17.90 & 1282 & 0.74 & $1365 \mathrm{w}$ & $\mathrm{V}_{\mathrm{NC}}(27)+\delta_{\mathrm{HNN}}(26)+\delta_{\mathrm{NCN}}(11)$ \\
\hline 42 & 1399 & 1.55 & - & - & $1402 \mathrm{~m}$ & $\delta_{\mathrm{HCH}}(72)$ \\
\hline 43 & 1400 & 0.12 & - & - & - & $\delta_{\mathrm{HCH}}(64)$ \\
\hline 44 & 1414 & 2.00 & - & - & $1403 \mathrm{~m}$ & $\delta_{\mathrm{HCH}}(74)$ \\
\hline 45 & 1442 & 8.65 & 1369 & 47.03 & $1416 \mathrm{sh}$ & $\mathrm{V}_{\mathrm{NC}}(58)$ \\
\hline 46 & 1524 & 10.94 & 1437 & 43.18 & $1483 \mathrm{~m}$ & $\mathrm{~V}_{\mathrm{NC}}(29)+\delta_{\mathrm{HNH}}(15)+\delta_{\mathrm{HNC}}(12)$ \\
\hline 47 & 1547 & 8.79 & 1526 & 12.31 & 1563 vs & $\delta_{\mathrm{HNH}}(43)+\delta_{\mathrm{HNN}}(18)$ \\
\hline 48 & 1561 & 23.94 & 1558 & 100.00 & $1584 \mathrm{~s}$ & $\delta_{\mathrm{HNH}}(67)$ \\
\hline 49 & 1590 & 14.92 & 1585 & 43.96 & $1628 \mathrm{~m}$ & $\mathrm{~V}_{\mathrm{NC}}(35)+\delta \mathrm{HNH}(20)$ \\
\hline 50 & 2934 & 0.01 & - & - & $2700 \mathrm{vw}$ & $\mathbf{V}_{\mathrm{CH}}(99)$ \\
\hline 51 & 2936 & 0.04 & - & - & $2709 \mathrm{vw}$ & $\mathrm{V}_{\mathrm{CH}}(\mathbf{1 0 0})$ \\
\hline 52 & 3030 & 0.01 & - & - & $2756 \mathrm{vw}$ & $\mathrm{V}_{\mathrm{CH}}(94)$ \\
\hline 53 & 3034 & 0.04 & - & - & $2775 \mathrm{vw}$ & $\mathrm{V}_{\mathrm{CH}}(93)$ \\
\hline 54 & 3041 & 0.00 & - & - & $2797 \mathrm{vw}$ & $\mathrm{V}_{\mathrm{CH}}(99)$ \\
\hline 55 & 3041 & 0.01 & - & - & 2910 w & $\mathrm{V}_{\mathrm{CH}}(98)$ \\
\hline 56 & 3176 & 100.00 & 3225 & 74.84 & $3122 \mathrm{~m}$ & $\mathrm{~V}_{\mathrm{NH}}(97)$ \\
\hline 57 & 3307 & 13.52 & 3300 & 40.73 & $3191 \mathrm{~m}$ & $\mathrm{~V}_{\mathrm{NH}}(96)$ \\
\hline 58 & 3311 & 3.02 & 3311 & 15.77 & 3309 w & $\mathrm{V}_{\mathrm{NH}}(96)$ \\
\hline 59 & 3391 & 8.67 & 3388 & 28.95 & $3322 \mathrm{w}$ & $\mathrm{V}_{\mathrm{NH}}(100)$ \\
\hline 60 & 3396 & 6.76 & 3396 & 22.14 & $3368 \mathrm{w}$ & $\mathrm{V}_{\mathrm{NH}}(100)$ \\
\hline
\end{tabular}

vs: very strong; s: strong; m: medium; w: weak; vw; very weak

$* \mathrm{~V}$ : stretching modes; $\delta$ : bending modes; $\Gamma$ : torsional modes. 
Table 4

Vibrational modes of the most stable guanazole- $\mathrm{H}_{2} \mathrm{O}$ complex (for VI)

\begin{tabular}{|c|c|c|c|c|c|c|}
\hline \multirow{2}{*}{ Mode } & \multicolumn{2}{|c|}{ Model II } & \multicolumn{2}{|c|}{ Model I } & \multirow{2}{*}{ Exp. } & \multirow{2}{*}{$\operatorname{PED}(\%)^{*}$} \\
\hline & Freq. & IIR & Freq. & IIR & & \\
\hline 13 & 502 & 89.67 & 516 & 94.16 & $566 \mathrm{w}$ & $\Gamma_{\mathrm{HNCN}}(80)+\delta_{\mathrm{HNH}}(10)$ \\
\hline 14 & 570 & 60.51 & 592 & 60.30 & $605 \mathrm{~m}$ & $\Gamma_{\mathrm{HNCN}}(70)$ \\
\hline 15 & 645 & 0.12 & 644 & 0.93 & $617 \mathrm{~m}$ & $\delta_{\mathrm{CNC}}(31)+\mathrm{V}_{\mathrm{NC}}(25)$ \\
\hline 16 & 686 & 2.18 & 689 & 2.88 & $722 \mathrm{w}$ & $\Gamma_{\mathrm{NNNC}}(60)+\Gamma_{\mathrm{NCNC}}(20)$ \\
\hline 17 & 745 & 7.82 & 746 & 9.56 & $767 \mathrm{vw}$ & $\Gamma_{\mathrm{NNNC}}(49)+\Gamma_{\mathrm{NCNC}}(30)$ \\
\hline 18 & 783 & 1.91 & 778 & 2.86 & $805 \mathrm{~m}$ & $\delta_{\mathrm{NCN}}(59)+\mathrm{V}_{\mathrm{NC}}(26)$ \\
\hline 19 & 967 & 19.61 & - & - & $951 \mathrm{w}$ & боHN $(51)+\delta$ HNC $(18)+\Gamma$ oHNN $(13)$ \\
\hline 20 & 998 & 5.75 & 988 & 3.46 & $1015 \mathrm{~m}$ & $\delta_{\mathrm{NCN}}(40)+\mathrm{V}_{\mathrm{NC}}(17)+\delta_{\mathrm{CNC}}(15)$ \\
\hline 21 & 1025 & 9.10 & 1024 & 10.35 & $1047 \mathrm{sh}$ & $\delta_{\mathrm{HNC}}(50)+\delta_{\mathrm{CNC}}(27)$ \\
\hline 22 & 1032 & 4.27 & 1030 & 1.83 & $1056 \mathrm{~s}$ & $\mathrm{~V}_{\mathrm{NC}}(38)+\delta_{\mathrm{HNC}}(35)$ \\
\hline 23 & 1086 & 2.23 & 1084 & 2.23 & $1120 \mathrm{vw}$ & $\mathrm{V}_{\mathrm{NC}}(61)+\delta_{\mathrm{HNC}}(17)$ \\
\hline 24 & 1126 & 0.64 & 1121 & 0.69 & $1149 \mathrm{vw}$ & $\delta_{\mathrm{HNC}}(26)+\mathrm{V}_{\mathrm{NC}}(23)+\delta_{\mathrm{NCN}}(13)$ \\
\hline 25 & 1283 & 0.70 & 1281 & 0.75 & $1345 \mathrm{~m}$ & $\delta_{\mathrm{HNC}}(53)+\mathrm{V}_{\mathrm{NC}}(22)$ \\
\hline 26 & 1371 & 45.49 & 1369 & 47.01 & $1409 \mathrm{~s}$ & $\mathrm{~V}_{\mathrm{NC}}(38)+\delta_{\mathrm{NCN}}(10)$ \\
\hline 27 & 1442 & 43.15 & 1437 & 43.07 & $1486 \mathrm{~s}$ & $\mathrm{~V}_{\mathrm{NC}}(56)$ \\
\hline 28 & 1516 & 50.56 & 1516 & 47.02 & 1558 vs & $\mathrm{V}_{\mathrm{NC}}(35)+\delta_{\mathrm{HNH}}(16)+\delta_{\mathrm{HNC}}(10)$ \\
\hline 29 & 1528 & 12.17 & 1525 & 11.95 & $1582 \mathrm{~s}$ & $\delta_{\mathrm{HNH}}(38)+\mathrm{V}_{\mathrm{NC}}(14)$ \\
\hline 30 & 1556 & 13.92 & 1557 & 44.69 & - & $\delta$ HNH $(29)$ \\
\hline 31 & 1563 & 100.00 & 1585 & 100.00 & $1621 \mathrm{vs}$ & $\delta_{\mathrm{HNH}}(66)$ \\
\hline 32 & 1589 & 41.56 & - & - & 1640sh & $\mathbf{V}_{\mathrm{NC}}(35)+\delta_{\mathrm{HOH}}(87)$ \\
\hline 33 & 3206 & 72.47 & 3218 & 75.75 & $3099 \mathrm{~m}$ & $\mathrm{~V}_{\mathrm{NH}}(99)$ \\
\hline 34 & 3297 & 45.55 & 3297 & 40.87 & $3236 \mathrm{w}$ & $\mathrm{V}_{\mathrm{NH}}(98)$ \\
\hline 35 & 3309 & 21.02 & 3308 & 15.99 & $3304 \mathrm{w}$ & $\mathrm{V}_{\mathrm{NH}}(98)$ \\
\hline 36 & 3344 & 202.89 & - & - & $3419 \mathrm{vw}$ & $\mathrm{V}_{\mathrm{OH}}(94)$ \\
\hline 37 & 3385 & 28.03 & 3384 & 29.33 & $3361 \mathrm{w}$ & $\mathrm{V}_{\mathrm{NH}}(100)$ \\
\hline 38 & 3394 & 22.88 & 3392 & 22.30 & 3393 w & $\mathrm{V}_{\mathrm{NH}}(99)$ \\
\hline 39 & 3551 & 33.70 & - & - & $3565 w$ & $\mathrm{~V}_{\mathrm{OH}}(98)$ \\
\hline
\end{tabular}

vs: very strong; s: strong; m: medium; w: weak; vw: very weak

$* \mathrm{~V}$ : stretching modes; $\delta$ : bending modes; $\Gamma$ : torsional modes

Tables 3 and 4 show vibrational modes of V1 structures, the most stable complex structures of the a 1:1 binding ratio in both solvents. Modes, bolded in the tables, are vibrations resulting from guanazole- $\mathrm{C}_{2} \mathrm{H}_{6} \mathrm{OS} / \mathrm{H}_{2} \mathrm{O}$ interactions. When Table 3 is examined, carbon-hydrogen stretching modes were calculated in the range of $2900-3040 \mathrm{~cm}^{-1}$ at weak intensity. In the recorded solution spectrum, C-H vibrations are seen at $2700-2900 \mathrm{~cm}^{-1}$. In the experimental spectrum of guanazole $/ \mathrm{C}_{2} \mathrm{H}_{6} \mathrm{OS}$ solution, bands at 1404 and $1402 \mathrm{~cm}^{-1}$ are from $\mathrm{C}_{2} \mathrm{H}_{6} \mathrm{OS}$ vibrations. In the experimental part of Table 3, 1011vs, $990 \mathrm{~m}$ and $888 \mathrm{~m}$ modes belong to $\mathrm{H}$ $\mathrm{C}-\mathrm{S}-\mathrm{C}$ torsional vibrations and these modes are calculated at 1004, 975, and $885 \mathrm{~cm}^{-1}$. The medium intensity band at $911 \mathrm{~cm}^{-1}$ belongs to a S-O stretching action, whereas the $648 \mathrm{~m}$ and $618 \mathrm{w}$ bands belong to S-C stretching vibrations. These modes were calculated at 908, 655 and $621 \mathrm{~cm}^{-1}$, respectively. It is surprising in Table 3 that the mode, which is the combination of H-N-C, N-C-N bending, and $\mathrm{NC}$ stretching vibrations, is calculated at $1024 \mathrm{~cm}^{-1}$ in implicit (Model I) calculations and $1123 \mathrm{~cm}^{-1}$ in explicit (Model II) calculations. Although this mode belongs to the internal vibration of guanazole, hydrogen bonding between the $12 \mathrm{H}$ atom of guanazole and the $18 \mathrm{O}$ atom of $\mathrm{C}_{2} \mathrm{H}_{6} \mathrm{OS}$ caused this shift.

In Table 4, strong O-H stretching vibrations are calculated at 3551 and $3344 \mathrm{~cm}^{-1}$. These modes correspond to the bands seen at 3565 and $3419 \mathrm{~cm}^{-1}$ in the experimental spectrum of the guanazole- $\mathrm{H}_{2} \mathrm{O}$ solution. The shoulder band at $1640 \mathrm{~cm}^{-1}$, which is not present in the spectrum of solid guanazole, was determined as the $\mathrm{H}-\mathrm{O}-\mathrm{H}$ angle-bending mode and this was calculated at $1589 \mathrm{~cm}^{-1}$. Another band not 
present in the spectrum of free guanazole is $951 \mathrm{w}$. This band is in the spectrum of the solution and it was calculated at $967 \mathrm{~cm}^{-1}$ with medium intensity. All of these calculated modes are quite compatible with experimental values and results from the literature [25].

\section{CONCLUSIONS}

In this study, solvent effects and hydrogen bonding interactions on the guanazole molecule were investigated through experimental and theoretical approaches. Two conformations of guanazole were taken into account. Geometry optimizations were done using the DFT/6-311++G(d,p) method and geometric parameters of stable geometries, total energies, NBO charges and vibrational frequencies were calculated by the same level of theory. In the experimental part, $\mathrm{C}_{2} \mathrm{H}_{6} \mathrm{OS}$ and aqueous solutions of the guanazole were prepared and experimental IR spectra were recorded in the mid-region. In order to describe the interaction between guanazole and solvent molecules in solutions, various models were made from experimental data, and the nature of interaction was determined. The results of the study can be summarized as follows:

- Guanazole may theoretically exist in two tautomeric structures guanazole (I) and guanazole (II). The probability of the presence of guanazole (I) is $100 \%$.

- Seven guanazole- $\mathrm{C}_{2} \mathrm{H}_{6} \mathrm{OS}$ and seven guanazole$\mathrm{H}_{2} \mathrm{O}$ complexes were obtained. All nitrogen atoms of guanazole were determined to be hydrogen bond acceptors and all hydrogen atoms are hydrogen bond donors. In addition, aqueous complexes of guanazole were found to form stronger hydrogen bonds compared to $\mathrm{C}_{2} \mathrm{H}_{6} \mathrm{OS}$ complexes.

- Guanazole is dissolves well in $\mathrm{C}_{2} \mathrm{H}_{6} \mathrm{OS}$ and $\mathrm{H}_{2} \mathrm{O}$ and homogeneous mixtures can be obtained in both solvents, but more stable complexes form with $\mathrm{H}_{2} \mathrm{O}$ molecules. With this property, guanazole is thought to be an ideal molecule for pharmacological purposes.

- According to the results of the spectral analysis, it was observed that new bands, which were not present in the solid phase spectrum, appeared in the IR spectrum of the aqueous solution of guanazole, and this was attributed to the formation of guanazole- $\mathrm{C}_{2} \mathrm{H}_{6} \mathrm{OS} / \mathrm{H}_{2} \mathrm{O}$ complexes. Among the $1: 1$ interactions, intermolecular $1 \mathrm{pO} \cdots \mathrm{H}-\mathrm{N}$ and $\mathrm{lpN} \cdots \mathrm{H}-\mathrm{O}$ interactions were determined to be the most stable structures for the complexes.
For these interactions, h-bond lengths were calculated to be about 1.78 and $1.90 \AA$, and interaction energies were $-7.10 \mathrm{~kJ} / \mathrm{mol}$ for the guanazole- $\mathrm{C}_{2} \mathrm{H}_{6} \mathrm{OS}$ (V1) complex and $-50.5 \mathrm{~kJ} / \mathrm{mol}$ for the guanazole- $\mathrm{H}_{2} \mathrm{O}$ (V1) complex.

- $8 \mathrm{H}, 9 \mathrm{H}$ and $12 \mathrm{H}$ atoms were the most positive atoms of the molecule and the hydrogenbonded complexes of the $\mathrm{O} \cdots \mathrm{H}-\mathrm{N}$ type formed with these atoms are more stable than the ones formed with other hydrogen atoms of the molecule.

- As expected, all physical and chemical properties of guanazole changed when passed from vacuum to solvent environment and important shifts occurred in the vibrational frequencies of guanazole.

Acknowledgements. The author would like to thank the Çankırı Karatekin University BAP department (GrantNo: FF150219B26) for financial support of this projects. A small portion of the work in this article was presented as an oral presentation at the "International Conference on Advances in Natural and Applied Sciences (ICANAS 2017)". The authors would like to thank the reviewers for their comments that helped to improve the manuscript.

\section{REFERENCES}

[1] J. A. Vick, E. H. Herman, Cardiovascular effects of guanazole, Toxic. App. Pharm., 16, 108-119 (1970). DOI: https://doi.org/10.1016/0041-008X(70)90167-5

[2] M. A. Hahn, H. R. Adamson, The disposition of the antitumour agent 3,5-diamino-1,2,4-triazole (guanazole) in mice, rats and dogs, Xenbiotica, 3, 247-255 (1973). DOI: https://doi.org/10.3109/00498257309151520

[3] C. Dave, M. A. Paul, Y. M. Rustum, Studies on the selective toxicity of guanazole in mice, Eur. J. Cancer., 14, 33-40 (1978).

[4] C. D. Selassie, E. J. Lie, T. A. Khwaja, Synthesis and evaluation of guanazole prodrugs as antineoplastic agents, J. Pharm. Sci., 70, 1281-1283 (1981). DOI: https://doi.org/10.1002/jps.2600701126

[5] W. Suter, F. Romagna, DNA repair induced by various mutagens in rat hepatocyte primary cultures measured in the presence of hydroxyurea, guanazole or aphidicolin, Mutat. Res-fund. Mol. M. 231, 251-264 (1990) DOI: https://doi.org/10.1016/0027-5107(90)90031-X

[6] J. A. Ho, C. V. Pickens, M. P. Gamscik, O. M. Colvin, R. E. Ware, In vitro induction of fetal hemoglobin in human erythroid progenitor cells, Exp. Hematol., 31, 586-591 (2003). DOI: https://doi.org/10.1016/S0301-472X(03)00086-9

[7] X. Zhao, M. R. Rosenberg, J. Wan, S. Zeng, W. Cui, Y. Xiao, Z. Li, Z. Tu, M. G. Casarotto, W. Hu, Design and synthesis of pinanamine derivatives as anti-influenza A M2 ion channel inhibitors, Antivir. Res., 96, 91-99 (2012).

DOI: https://doi.org/10.1016/j.antiviral.2012.09.001 
[8] V. K. Kumar, G. Keresztury, T. Sundius, R. J. Xavier, Hydrogen bonding and molecular vibrations of 3,5 diamino-1,2,4-triazole, Spectrochim. Acta, Part A. 61, 261-267 (2005).

DOI: https://doi.org/10.1016/j.saa.2004.03.039

[9] L. Guennoun, J. El Jastimi, F. Guédira, K. Marakchi, O.K. Kabbaj, A. El Hajji, S. Zaydoun, Molecular geometry and vibrational studies of 3,5-diamino-1,2,4triazole using quantum chemical calculations and FT-IR and FT-Raman spectroscopies, Spectrochim. Acta, Part A. 78, 347-353 (2011).

DOI: https://doi.org/10.1016/j.saa.2010.10.019

[10] A. Ray, M. Samiran, M. R. Georgina, A novel hydroxobridged cyclic tetranuclear copper(II) complex using the guanazole ligand: Synthesis, crystal structure and thermal analysis, Inorg. Chem. Com., 11, 1256-1259 (2008). DOI: https://doi.org/10.1016/j.inoche.2008.07.010

[11] I. Matulková, I. Císařová, P. Němec, J. Kroupa, P. Vaněk, N. Tesařová, Organic salts of guanazole - Seeking for new materials for second harmonic generation, $J$. Mol. Struct., 1044, 239-247 (2013). DOI: https://doi.org/10.1016/j.molstruc.2012.11.011

[12] P. Cui, L. Xiaohui, Construction of two new Zn(II)guanazole frameworks via varying organic carboxylate ligands, J. Mol. Struct., 1081, 182-186 (2015). DOI: https://doi.org/10.1016/j.molstruc.2014.09.081

[13] H. Zhao, D. Yanli, L. Haiping, Two new luminescent $\mathrm{Zn}$ (II) compounds constructed from guanazole and aromatic polycarboxylate ligands, J. Mol. Struct., 1105, 112-117 (2016).

DOI: https://doi.org/10.1016/j.molstruc.2015.10.046

[14] G. Karpińska, J. C. Dobrowolksi, On tautomeric equilibria in the guanazole molecule. A DFT study, J. Mol. Struct. THEOCHEM., 853, 7-17 (2008). DOI: https://doi.org/10.1016/j.theochem.2007.11.036

[15] S. Miertuš, E. Scrocco, J. Tomasi, Electrostatic interaction of a solute with a continuum. A direct utilizaion of $\mathrm{AB}$ initio molecular potentials for the prevision of solvent effects, Chem. Phys., 55, 117-129 (1981). DOI: https://doi.org/10.1016/0301-0104(81)85090-2
[16] B. N. Swanson, Medical use of dimethyl sulfoxide (C2H6OS). Reviews in Clinical \& Basic Pharmacology, 5, 1-33 (1985).

[17] R. D. Dennington, T. A. Keith, J. M. Millam, GaussView 5, Gaussian, Inc. 2008.

[18] Frisch, M. J. et al. Gaussian 09. Gaussian, Inc.: Wallingford, CT, 2009.

[19] M. H. Jamróz, Vibrational Energy Distribution Analysis VEDA 4, Warsaw 2004.

[20] N. Sundaraganesan, G. Elango, S. Sebastian, P. Subramani, Molecular structure, vibrational spectroscopic studies and analysis of 2-fluoro-5-methylbenzonitrile, Indian J. Pure Ap. Phy., 47, 481-490 (2009). DOI: http://hdl.handle.net/123456789/5056.

[21] S. F. Boys, F. Bernardi, The calculation of small molecular interactions by the differences of separate total energies. Some procedures with reduced errors, Mol. Phys., 19, 553-559 (1970).

[22] M. T. Bilkan, Quantum chemical studies on solvent effects, ligand-water complexes and dimer structure of 2,2'-dipyridylamine, Phys. Chem. Liq., 57, 100-116 (2019).

DOI: https://doi.org/10.1080/00319104.2018.1423564

[23] G. L. Starova, O. V. Frank-Kamanetskaya, E. F. Shibanova, V. A. Lopyrev, M. G. Voronkov, V. V. Makarskii, X-ray diffraction examination of the molecular structure of guanazole (3,5-diamino-ih-i,2,4-triazole), Khimiya Geterotsiklicheskikh Soedinenii. 10, 14221423 (1979).

[24] Y. Z. Zheng, Y. Zhou, Q. Liang, D. F. Chen, R. Guo, R. C. Lai, Hydrogen-bonding Interactions between Apigenin and Ethanol/Water: A Theoretical Study SCI. REP-UK, 6, 34647-34660 (2016). DOI: https://doi.org/10.1038/srep34647

[25] M. T. Bilkan, Structural and spectroscopic studies on dimerization and solvent-ligand complexes of theobromine, J. Mol. Liq., 238, 523-532 (2017). DOI: https://doi.org/10.1016/j.molliq.2017.05.051 